\title{
Phymosia (Malvaceae) a new genus for the flora of Africa, with nomenclatural notes
}

\section{Duilio lamonico $^{1}$ (D) \& Ridha El Mokni ${ }^{2}$ (i)}

Key words: Alien species, Phymosia umbellata, Tunisia, typification.

Ključne besede: Tujerodne vrste, Phymosia umbellata, Tunizija, tipizacija.

\begin{abstract}
As part of ongoing studies of Tunisian Malvaceae, a population of Phymosia umbellata was discovered in Monastir city. It represents the first generic record for the national and continental flora. Morphological characters, as well as ecological data are given. A list of all the accepted names in Phymosia, their synonyms and types is also provided, with nomenclatural notes about some accepted Phymosia species.

Izvleček

Med dolgoročnimi raziskavami družine Malvaceae v Tuniziji smo v mestu Monastir odkrili populacijo vrste Phymosia umbellata. Predstavlja prvi generičen zapis pojavljanja te vrste $\mathrm{v}$ nacionalni in kontinetalni flori. Predstavili smo morfološke značilnosti in ekološke podatke. Navajamo seznam vseh veljavnih imen rodu Phymosia, njihove sinonime in tipe z nomenklaturnimi pripombami o nekaterih vrstah rodu Phymosia.
\end{abstract}

Received: 23. 3. 2020

Revision received: 28. 4. 2020

Accepted: 29. 4. 2020

\footnotetext{
1 Department PDTA, University of Rome Sapienza, Via Flaminia 72, 00196-Rome, Italy. E-mail: d.iamonico@yahoo.it

2 Department of Pharmaceutical Sciences “A”, Laboratory of Botany, Cryptogamy and Plant Biology, University of Monastir, Avenue Avicenna, 5000-Monastir, Tunisia. E-mail: ridha.elmokni@fphm.rnu.tn
} 


\section{Introduction}

The first comprehensive revision of the tropical genus Phymosia Desv. ex Ham., after its original publication (Hamilton 1825: 49-50, who proposed the new genus based on calyx and fruit structures, segregating just the Linnaean Malva abutiloides $\mathrm{L}$. which is, therefore, the holotype of the genus Phymosia), was made about 150 year later by Fryxell (1971), who recognized the following eight species: P. abutiloides (L.) Desv. ex Ham., P. anomala Fryxell, $P$. crenulata (Brandegee) Fryxell, P. floribunda (Schltdl.) Fryxell, P. pauciflora (Baker f.) Fryxell, P. rosea (DC.) Kearney, P. rzedowskii Fryxell, and P. umbellata (Cav.) Kearney. No infraspecific taxa were considered by Fryxell (1971).

As part of an ongoing study on the family Malvaceae (e.g., Iamonico 2010, 2014a, 2014b, 2016, 2018, Iamonico \& Peruzzi 2014, Iamonico \& Valdés, 2017, Iamonico $\&$ Del Guacchio 2020) and the alien Flora of Tunisia (El Mokni \& Iamonico 2018a, 2018b, 2019, Iamonico \& El Mokni 2017, 2019a, 2019b), field surveys allowed to find a population of Phymosia umbellata. The genus results new both for the Country and the whole Africa (SANBI 2012). A description of the African population, as well as distribution and habitat in Tunisia are provided. Nomenclatural notes on other Phymosia names were also given.

\section{Materials and methods}

The research is based on field surveys [collected specimens are deposited at HFLA and Herb. Univ. Monastir: TUNISIA. Monastir: Monastir-South, gardens, $15 \mathrm{~m}$ a.s.l., 05 Dec 2018, R. El Mokni \& D. Iamonico s.n. (Herb. Univ. Monastir!); ibidem (HFLA!); ibidem, 08 Mar 2020 (Herb. Univ. Monastir!)], analysis of relevant literature, and examination of specimens preserved at BR, BM, GH, GOET, K, LINN, NY, and P (herbarium codes follow Thiers 2020+).

The articles cited through the text follow the International Code of Nomenclature for algae, fungi, and plants (Turland et al. 2018, hereafter ICN).

The names (basionyms) are listed in alphabetical order.

\section{Results and discussion}

\section{First record for Tunisian and African floras}

Phymosia umbellata is a species native to Mexico (Fryxell 1971), whereas it was recently found as alien in Europe, in Greece (Rodos Island; Galanos 2015), and Spain (Barcelona Province; Gómez-Bellver et al. 2016).
A single population of Phymosia umbellata was found at Monastir city, CE-Tunisia (Figure 1), at elevation 15-20 m. It comprises 7 individuals which occupy an area of about $20 \mathrm{~m}^{2}$. We observed the flowering time from December to January, whereas the fruiting time is February-March. This population represents the first record of the species for the Flora of Africa. At the current state of knowledge, we consider Phymosia umbellata as a casual alien species for Tunisia and Africa. However, future monitoring will be carried out to check the eventual naturalization of the species.

\section{Nomenclature}

\section{Note on the type of Malva rosea (三 Phymosia rosea)}

Candolle (1824: 435) validly described Malva rosea giving a short diagnosis, the provenance ("montium NovaeHispaniae"), and citing "fl. mex. ic. ined.". These latter abbreviated words refer to Icones Florae Mexicanae, a series of paintings (included in the Torner's collection) which would accompany the projected Mexican flora related to the Sessé and Mociño's expedition aimed to explore the flora of Caribbean, Mexico and northern Central America (with forays also in Baja and Alta California and as far north as Nootka and Alaska) (see Hunt Institute For Botanical Documantation 2020).

Fryxell (1971: 168) reported "Type: Calque des Dessins de la Flora du Mexique de Moçiño et Sessé . . . , No. 58 (F, G, US)". This cited work was published by Candolle (1874) and includes a list of the taxa of Icones Florae Mexicanae which served as type of the taxa listed in his Prodromus, as reported in both the Title ("Calque des Dessins de la Flora du Mexique de Moçiño et Sessé qui ont servi de type espécies dans le systema ou le prodromus") and the Introduction (Candolle 1874: 1) (see also Del Guacchio et al. 2016: 149). The "No. 58" cited by Fryxell (l.c.) refers to the number of planche reported by Candolle (1874: 6; see https://www.biodiversitylibrary.org/ item/175033\#page/95/mode/lup) for Malva rosea. We verified that 58 is also the number of the painting of Icones Florae Mexicanae of Malva rosea.

Note, finally, that Candolle (1824) alwalys reported "v. s." (vidi siccam) when he examined herbarium specimens [see for example Malvaviscus pilosus (DC.) Swartz; Candolle 1824: 445], whereas this information was not given for Malva rosea.

All things considered, as in other cases [for example for Malvaviscus penduliflorus (Iamonico \& El Mokni in prep.)], Candolle (1824: 435), by reporting "fl. mex. ic. ined.", published its diagnosis of Malva rosea based on 


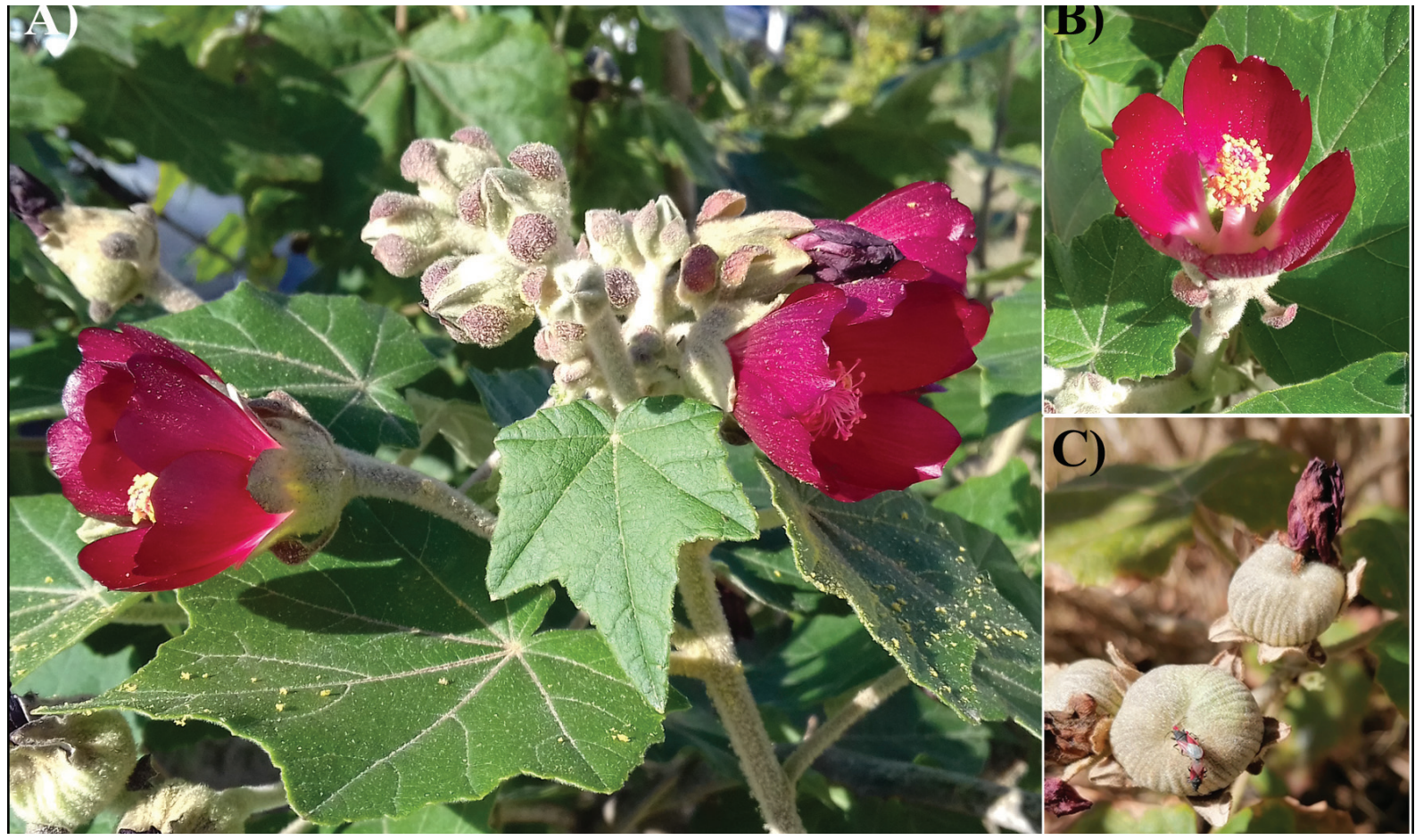

Figure 1: Phymosia umbellata in Tunisia: A) inflorescence with leaves, B) details of flower, C) schizocarps (photos by R. El Mokni). Slika 1: Phymosia umbellata v Tuniziji: A) socvetje z listi, B) podrobnosti cvetov, C) pokovec (fotografije R. El Mokni).

the illustration of Icones Florae Mexicanae. The quotation by Fryxell (1971: 168) of the herbaria F, K, and US likely indicates that he seen copies (we traced an illustration of Malva rosea at $\mathrm{F}$ (same of that included in Icones Florae Mexicanae, but non colored; see https:// fm-digital-assets.fieldmuseum.org/369/620/30485.jpg). Anyway, the image no. 58 of Icones Florae Mexicanae can be considered as the holotype of the name Malva rosea according to the Art. 9.1 of ICN, and the cosiderations by McNeill (2014).

\section{Notes on the typification of Sphaeralcea crenulata (三 Phymosia crenulata)}

Fryxell (1971: 161) stated for Sphaeralcea crenulata "Type: MEXICO: Puebla: Barranca Cerro de Paxtle, Purpus 2601 (UC)". The typification is correct and is to be considered as lectotypification according to the Art. 7.11 of ICN. Moreover, although Fryxell (1971: 161) did not report any barcode, there is only one specimen at UC (UC-124978) which label data correspond to those indicated by the author.

Note that Fryxell (1971) also listed further two identical Purpus' specimens at GH, and MO (barcode
MO-531995), but we have not been able to trace the images of these exsiccata.

\section{Typification of Sphaeralcea galeottii (= Phymosia umbellata)}

Sphaeralcea galeottii was validly described by Turczaninow (1858) through a diagnosis, the provenance ("Oxaca Mexici alt. 3000 ped."), and the collector ("Galeotti n. 4102").

Fryxell (1971: 163), by reporting "Type: Veracruz, Tlachichuca, al pié del Volcán, s.d., Galeotti 4102 (BR-3 sheets)", did not indicate which BR specimen was to be considered as type. According to the Arts. 7.11 and 9.17 of ICN, a second-step typification is necessary.

We traced the three BR specimens cited by Fryxell (1971: 163), i.e. BR-0000005215393, BR-0000005178476, and BR-0000005179817. We here designate the specimen BR-0000005215393 as the lectotype of the name Sphaeralcea galeottii (second-step typification) since an image is online available just for it ${ }^{1}$. The other two BR specimens are isolectotypes. A further isolectotype was found at K (K-000328823).

\footnotetext{
1 Since the COVID-19 situation, we had not the possibility to obtain images of the other two specimens (BR0000005178476, and BR-0000005179817).
} 


\section{Typification of Sphaeroma floribunda (三 Phymosia floribunda)}

Sphaeroma floribunda was validly published by Schlechtendal (1827: 53) who provided a short diagnosis, a detailed description, the provenance ("Ad Oajaca"), and the collector ("Mühlenpfordt")). Fryxell (1971: 160) given a wide discussion about the Mühlenpfordt's collection, reaching to the conclusion that orginal material no longer exists since Mühlenpfordt's specimens were included into the Halle's herbarium at B, destroyed during the II World War. As a consequence, Fryxell (1971: 157) proposed a neotype "Oaxaca: Yavesía, Galeotti 4088 (BR)". We traced three pertinent specimens at BR, collected by H. G. Galeotti and numbered as “4088”: BR-000000517838, BR-0000005188031, BR-000000517897. According to the Art. 9.17 of ICN a second-step typification is necessary and we here select the specimen BR-000000517897 as the other two $\mathrm{BR}$ specimens are isoneotypes. We found a further isoneotype at K (K-000328820).

\section{Typification of Sphaeroma floribunda var. pauciflora (三 Phymosia pauciflora)}

Baker (1893: 365) proposed the name Sphaeroma floribunda var. pauciflora on the basis of a Mexican collection by T. Coulter, numbered as "No. 800". Fryxell (1971: 163) reported: "Type: MEXICO: Hidalgo: Zimapan, Coulter 800" without indication of the herbarium. In the successive page of his work, Fryxell (1971: 164) listed three Coulter's specimens at GH, F, and $\mathrm{K}$, but he did not indicate which specimen was the type.

According to the Arts. 7.11, 9.17, and 9.22 of ICN the Fryxell's typification proposal can be considered as valid and a second-step typification is here provided.

We traced three specimens, one at GH (GH-00058142), and two at K (K000328821 and K-000328822), which are part of the original material used by Baker (1893: 365 ) to describe Phymosia floribunda var. pauciflora. We here designate the specimen K-000328822 the lectotype of the name Sphaeroma floribunda var. pauciflora (secondstep typification), since it bears a part of one plant displaying more characters. The other two specimens $(\mathrm{GH}-$ 00058142 and K-000328821) are isolectotypes.

Note that Fryxell (1971: 164) also listed a further Coulter' specimen at F, but we have not been able to trace this exsiccatum.

\footnotetext{
2 Philipp August Friedrich Mühlenpfordt (1803-1891) was a German botanist, Professor of Zoology and Botany at the Polytechnical School of Hannover (Mühlenpfordt 1847).
}

\section{Taxonomic treatment}

A list of all the currently accepted Phymosia species, with homotypic synonyms and correct types is reported.

Phymosia abutiloides (L.) Desv. ex Ham., Prodr. Pl. Ind. Occid.: 49. $1825 \equiv$ Malva abutiloides L., Sp. Pl. Ed. 2 2: $971.1763 \equiv$ Sphaeralcea abutiloides (L.) G.Don, Gen. Syst. 1: 465. 1831 - Lectotype (designated Fryxell, 1971: 157): [Icon] t. 1. f. 1 in Dillenius (1732). Image of the lectotype available at https://bibdigital. rjb.csic.es $/$ viewer $/ 10700 /$ ?offset=\#page $=11 \&$ viewer $=$ pi cture\&o=bookmark\&n=0\&q=

Chorology: Bahamas (at sea level) and Haiti (up to 1500 m a.s.l.) (Fryxell 1971: 157).

Phymosia anomala Fryxell, Madroño 21(3): 167. 1971 - Holotype: Mexico, Hidalgo, Real del Monte, Aug 1946, Martinez 15054 (MO-1313132!). Image of the holotype available at http://legacy.tropicos.org/Image/34333

Chorology: Endemic to Hidalgo and Michoacán, Mexico (Fryxell 1971: 168).

Phymosia crenulata (Brandegee) Fryxell, Madroño 21(3): 161. $1971 \equiv$ Sphaeralcea crenulata Brandgee, Univ. Calif. Publ. Bot. 3(8): 384-385. 1909 - Lectotype (designated by Fryxell 1971: 157, first-step; second-step, proposed here according to the Art. 9.17 of ICN): Mexico, Puebla, Barranca Cerro de Paxtle, Jul 1907, Purpus 1601 (UC-124978!). Image of the lectotype available at https://plants.jstor.org/stable/10.5555/al.ap.specimen.uc124978?searchUri=fil ter\%3Dname\%26so\%3Dps_group_by_genus_speci es\%2Basc\%26Query\%3DSphaeralcea\%2Bcrenulata; Isolectoypes: GH (not traced, fide Fryxell 1971: 163), and MO-531995 (image not traced, fide Fryxell 1971: 163, but see the form at http://legacy.tropicos.org/ Specimen/2159962).

Chorology: Puebla, Mexico (Fryxell 1971: 163).

Phymosia floribunda (Schltdl.) Fryxell, Madroño 21(3): 157. $1971 \equiv$ Sphaeroma floribunda Schltdl., Linnaea 11: 353. $1827 \equiv$ Malva floribunda (Schltdl.) Steud., Nomencl. Bot. (ed. 2): 2: $94.1841 \equiv$ Sphaeralcea floribunda (Schltdl.) Walp., Repert. Bot. Syst. 2: 789.1843 - Neotype (designated by Fryxell 1971: 157, first-step; second-step, proposed here according to the Art. 9.17 of ICN): Mexico, Oaxaca, Yavezia, Nov 1840, Galeotti 4088 (BR-000000517897!) (Figure 1). Isoneotypes: BR-000000517838!, BR- 
0000005188031!, and K-000328820! (designated here, image available at http://apps.kew.org/herbcat/ getImage.do?imageBarcode=K000328820).

Chorology: North-central Oaxaca, Mexico (Fryxell 1971: 161).

Phymosia pauciflora (Backer) Fryxell, Madroño 21(3): 163. 1971 ESphaeralcea floribunda var. pauciflora Baker, J. Bot. 31: 365. 1893 - Lectotype (designated by Fryxell 1971: 163, first-step; second-step, proposed here according to the Art. 9.17 of ICN): Mexico, Hidalgo, s.d., Coulter 800 (K-000328822!). Image of the lectotype available at http://apps.kew.org/herbcat/getImage. do?imageBarcode=K000328822; Isolectoypes: GH00058142! (image available at https://s3.amazonaws. com/huhwebimages/0014D61A75A445F/type/ full/58142.jpg), K-000328821 (image available at http://apps.kew.org/herbcat/getImage.do?image Barcode $=$ K000328821), and F (not traced, fide Fryxell 1971: 163).

Chorology: Mexico (Fryxell 1971: 163).

Phymosia rosea (DC.) Fryxell, Madroño 21(3): 168. 1971 - Holotype: [icon] Malva rosea no. 58 in Icones Florae Mexicanae (unpublished). Image of the holotype available at https://huntbot.org/torner/sites/default/ files/illustration/0745.JPG

Chorology: Central America, from Guatemala to South Mexico (Fryxell 1971: 172).

Phymosia rzedowski Fryxell, Madroño 21(3): 172-173. 1971 - Holotype: Mexico, $2 \mathrm{~km}$ a SE de San Pablo Ixayoc, munic. de Texcoco, fondo de cañada con vegetatión de bosque de Alnus con Abies, Fraxinus, y Quercus, 2600 m a.s.l., 03 Aug 1967, Rzedowski 24187 (ENCB-003465!). Image of the holotype available at http://collections.umontpellier.fr/

Chorology: Endemic to Texcoco, Mexico; occurring only in its locus classicus (Fryxell 1971: 173).

Phymosia umbellata (Cav.) Kearney, Leafl. W. Bot. 5(12): 190. 1949 三 Malva umbellata Cav., Icon. 1: 64, t. 95. $1791 \equiv$ Sphaeralcea umbellata (Cav.) G. Don, Gen. Hist. 1: 465. 1831 三 Sphaeroma umbellatum (Cav.) Schltdl., Linnaea 11: 352.1837 - Lectotype (designated by Fuertes \& Fryxell 1993: 661-662): Spain, Ex. H. Matr. (Horti [Regi Botanici] Matritensis), cultivated at the Botanic Garden of Madrid, 1800 , s.c. s.n. (MA-CAV-475960!). Image of the lectotype available at http://herbario.rjb.csic.es/zoom3. php?filename=Malva_umbellata_475960; Isolectotypes: MA-CAV-475959! (http://herbario.rjb.csic.es/
zoom3.php?filename=Malva_umbellata_475959), MA-CAV-475961! (http://herbario.rjb.csic.es/ zoom3.php?filename=Malva_umbellata_475961), MA-CAV-475962! (http://herbario.rjb.csic.es/zoom3. php?filename=Malva_umbellata_475962).

= Sphaeralcea galeottii Turcz., Bull. Soc. Nat. Mosc. 31: 186. 1858 - Lectotype (designated by Fryxell 1971: 165, first-step; second-step typification, here proposed): Mexico, Veracruz, Tlachichuca, al pié del Volcán, s.d., Galeotti 4102 (BR-0000005215393!). Image of the lectotype available at http://www.br.fgov. be/research/COLLECTIONS/HERBARIUM/detail. php?ID=444674; Isolectoypes: BR-0000005178476, BR-0000005179817, and K-000328823 (image available at http://apps.kew.org/herbcat/getImage.do?image Barcode $=$ K000328823).

\section{Acknowledgements}

Thanks are due to Directors and Curators of all the quoted herbaria for their support. Special thanks to F. Verloove (Herbarium BR) for the images of the type of Sphaeroma floribunda (BR-000000517897, BR-000000517838, and BR-0000005188031).

Duilio lamonico (D), https://orcid.org/0000-0001-5491-7568 Ridha El Mokni (D), https://orcid.org/0000-0003-3849-1039

\section{References}

Baker, E.G. 1893: Synopsis of Genera and Species of Malveae. J. Bot. 31: 361-368.

Candolle, A. de (Ed.) 1824: Prodromus Systematis Regni Vegetabilis 1. Treuttel et Würz, Argentorati et Londini.

Candolle, A. de 1874: Flora du Mexique de Moçiño et Sessé qui ont servi de type espécies dans le systema ou le prodromus 1. Genéva.

Del Guacchio, E., Cennamo, P., Vásquez Torrez, M. \& Menale, B. 20I6: Where arts meets taxonomy: identity of Erythrina latea (Fabaceae). Phytotaxa 255(2): 144-152. http://dx.doi.org/10.11646/ phytotaxa.255.2.3

Dillenius, J.J. 1732: Hortus Elthamensis 1. Published by the author, London.

El Mokni, R. \& Iamonico, D. 20 I8a: A new record for the non-native flora of Tunisia, Eclipta prostrata (Ecliptinae, Asteraceae), and a note on the national status of Erigeron bonariensis, Lepidium didymum, and Symphyotrichum squamatum. Fl. Medit. 28: 145-153. https://doi. org/10.7320/FlMedit28.145

El Mokni, R. \& Iamonico, D. 201 8b: Three new records of Senecioneae (Asteraceae) for the allochthonous Tunisian Flora. Fl. Medit. 28: 385-392. https://doi.org/10.7320/FlMedit28.000 
El Mokni, R. \& Iamonico, D. 2019: Bassia scoparia and Sesuvium portulacastrum, two new naturalized aliens to the Tunisian flor. Fl. Medit. 29: 191-196. https://doi.org/10.7320/FlMedit29.191

Fryxell, P.A. 1971: A revision of Phymosia. Madrońo 21: 153-174.

Fryxell, P.A. \& Stelly, D.M. 1993: Documented chromosome numbers 1993: 2. Additional chromosome counts in the Malvaceae. Sida 15: 639-647.

Fuertes, J. \& Fryxell, P.A. 1993: Nomenclatural notes on some Malvaceae species described by Cavanilles. Taxon 42: 661-664.

Galanos, C.J. 2015: The alien flora of terrestrial and marine ecosystems of Rodos island (Se Aegean), Greece. Willdenowia 45: 261-278.

Gómez-Bellver, C., Álvarez, H. \& Sáez, L. 2016: New contributions to the knowledge of the alien flora of the Barcelona province (Catalonia, Spain). Orsis 30: 167-189.

Hamilton, W. 1825: Prodromus Plantarum Indiae Occidentalis 16. Treuttel et Würz, Londini.

Hunt Institute For Botanical Documantation 2020: Persons, Collections and Topics. Torner. http://www.huntbotanical.org/art/show.php?10 (last accessed 15 March 2020).

Iamonico, D. 2010: Malva subovata subsp. bicolor, comb. \& stat. nov. (Malvaceae). Ann. Bot. Fennici 47: 312-314.

Iamonico, D. 2014a: Lavatera stenopetala subsp. plazzae comb. et stat. nov. Pl. Ecol. Evol. 147(2): 293-298. doi: http://dx.doi.org/10.5091/ plecevo.2014.920

Iamonico, D. 2014b: (2261) Proposal to reject the name Lavatera micans (Malva micans) (Malvaceae). Taxon 63(1): 191. doi: http:// dx.doi.org/10.12705/631.22

Iamonico, D. 2016: Nomenclatural notes and morphological observations on Malva subovata s.l. (Malvaceae). Phytotaxa 275(1): 23-34. http://dx.doi.org/10.11646/phytotaxa.275.1.3

Iamonico, D. 2018: Nomenclatural notes on some annual mallows (Malvaceae). Acta Bot. Croat., 77(1): 28-35. https://doi.org/28-35. 10.1515/botcro-2017-0018

Iamonico, D. \& Del Guacchio, E. 2017: Typification of the names in Malva cretica s.l. (Malvaceae). Phytotaxa 295(3): 280-286. https://doi. org/10.11646/phytotaxa.295.3.9

Iamonico, D. \& El Mokni, R. 2017: Amaranthus palmeri, a second record for the African flora and notes on $A$. sonoriensis nom. nov. Bothalia 47(1): a2100. https://doi.org/10.4102/abc.v47i1.2100
Iamonico, D. \& El Mokni, R. 2019a: A new addition to the alien flora of Tunisia, Amaranthus spinosus L. (Amaranthaceae s.1.), with notes on $A$. diacanthus Raf.. Acta Bot. Croat. 78(1): 91-94. https://doi. org/10.2478/botcro-2018-0009

Iamonico, D. \& El Mokni, R. 2019b: On Atriplex canescens (Chenopodiaceae s. str./ Amaranthaceae s. 1.) in Tunisia: nomenclatural and morphological notes on its infraspecific variability. Hacquetia 18(1): 119-127. https://doi.org/10.2478/hacq-2018-0008

Iamonico, D. \& Peruzzi, L. 2014: Typification of Linnaean names in Malvaceae for the Italian Flora. Taxon 63(1): 161-166. http://dx.doi. org/10.12705/631.11

Iamonico, D. \& Valdéz, B. 2017: Typification of Linnaean and Cavanilles names in the genus Malva (Malvaceae) for the Spanish flora. Taxon 66(2): 441-444. https://doi.org/10.12705/662.11

Iamonico, D. \& Del Guacchio, E. 2020: Linnaean names in the tribe Malveae for North and Central American Floras. J. Torr. Bot. Soc.: in press.

McNeill, J. 2014: Holotype specimens and type citations: General issues. Taxon 63(5): 1112-1113.

Mühlenpfordt, P.A.F. 1847: Correspondence: Mühlenpfordt (Friedrich) and Engelmann (George). <https://www.biodiversitylibrary. org/item/151711\#page/1/mode/1up> (last accessed 13 March 2020)

SANBI 2012: Biodiversity of life. Malvaceae Juss. http://www.ville-ge. $\mathrm{ch} / \mathrm{musinfo} / \mathrm{bd} / \mathrm{cjb} /$ africa/details. php?langue $=a n \& i d=187703$ (last accessed 15 March 2020).

Schlechtendal, D.F.L. von 1827: De Plantis Mexicanis. Linnaea 11 349-380.

Thiers, B. 2020+ [continuously updated]: Index herbariorum, a global directory of public herbaria and associated staff. New York Botanical Garden's Virtual Herbarium. http://sweetgum.nybg.org/ih/ (last accessed 15 March 2020)

Turczaninow, N.S. 1858: Animadversiones in secundam partem herbarii Turczaninowianii, nunc universitatis caesareae charkowiensis. Bull. Soc. Imp. Naturalistes Moscou 31(1): 185-250.

Turland, N.J., Wiersema, J.H., Barrie, F.R., Greuter, W., Hawksworth, D.L., Herendeen, P.S., Knapp, S., Kusber, W.-H., Li, D.-Z., Marhold, K., May, T.W., McNeill, J., Monro, A.M., Prado, J., Price, M.J. \& Smith, G.F. (eds.) 2018: International Code of Nomenclature for algae, fungi, and plants (Shenzhen Code). adopted by the Nineteenth International Botanical Congress, Shenzhen, China, July 2017. Regnum Vegetabile 159: 1-254. 